\title{
巻頭言
}

日本ポーラログラフ学会に御支援を

\author{
楠 文代
}

\section{Please support The Polarographic Society of Japan.}

\section{Fumiyo Kusu}

日本ポーラログラフ学会には親しみを 感じているので、巻頭言を 2009 年に書か せていただいた。平成 24 年度会長を拝命 し、まさかの巻頭言への再登場となった。 正直、戸惑いは隠せない。樹を切った後 にこれは大変とばかりにひこばえが勢い よく育ち、樹木や森がさらに健やかに育 つという。樹木を切った大変さに倣って 本会が育つことを期待する。幸いにも、 相樂隆正編集理事、白井理会計理事、西 直哉庶務理事はじめ理事会メンバーは実 力の優れた先生方が揃っていて、より良 い学会作り・学会運営に頑張っている現 況がある。

昨年、日本は大震災と原発事故に見舞 われ、さらに世界の経済事情も厳しい状 況が続いて大変な年であった。その中で、 なでしこジャパンが女子サッカーワール ドカップで優勝できたことは、サッカー ファンでなくてもおおいに喜び励まされ た。確かに日本女子は体力的には決して 恵まれていないから、奇跡というような 声まで聞こえていた。なぜ勝てたか?こ れは、日本人らしい素質が活かされたと 考える。お互いの知恵を出し合い、協力 と連携を遺憾なく出し切り、忍耐強く試 合を進められたから勝てた。日本は農耕 民族として今に至っている。狩猟民族と
は違って耕地を協力して耕し、天候と相 談しながら種をまき、辛抱強く育つのを 待つ。あまり議論を好まない、状況を伺 いながらの生活であったに違いない。し かし、いったん親交関係が成り立つとそ の絆は強い。ディベートが下手な日本人 が、そういう邑で協力連携関係を築いた 共同作業を進めるときは強い。このよう な力は、はやぶさの成功例にも示されて きた。

そのような日本人らしい力は、日本 ポーラログラフ学会にずっと蓄えられて きているように感じている。確かに滴下 水銀を使ったポーラログラフィーの研究 や講演は非常に少ない。しかし約 250 名の会員を擁し、ポーラログラフィーの ノスタルジアでなくて真に学問の面白さ を進めている。ポーラログラフィーを源 流とする電気化学が、流行に飲み込まれ ずにその時代時代に必要な視点の学問を 築き、世の中に科学的に正しい事柄を発 信し、文化と科学の発展に寄与する、そ れが本学会の役目と思ってきた。

昨今、インターネットは国際的に政治 にも影響する勢いで爆発的に拡がってき た。一方で真に科学的に正しくない、妥 当でない情報が世の中に汇濫することは われわれの生活が驾かされる時代とも言 
える。誰もがネットで得た情報を鵜吞み にしている状態が、なんとなく多数が声 を上げればそれに流される。そんな世の 中だから学会は以前にもましてしっかり しなければならない。学問の府として重 要な役目を託されている。科学の発信元 であってお互いがそういう観点で情報交 換をする。その意味で、アーカイブをた どれば、しっかりした情報を 60 年間も発 信してきたし、当然これからも発信し続 けることが期待される。発信するのは会 員。特に若い会員達には学会の仲間を一 杯作ってほしいと思う。ディベートが下 手な日本人が協力連携関係を築き、情報 の質向上に貢献する。

自分自身を振り返って多くの恩恵を受 けてきた。学会に参加して、ディベート とはほど遠く、教えてもらうことばかり であった。例えば、炭素電極の材料と性 能についてご指導いただいた結果として、 酸度計開発や電解プレカラム作りに繋げ たことは、学会活動の一種の成功体験と 感じている。

『電気分析化学の未来』について伊豆 津公佑先生からいただいたメッセージは、 電気分析の実用面を頑張ろうとした時の 私には嬉しかったので、これをそのまま 若い世代に伝えたい。

『電気分析化学の未来 :

測定原理、理論、方法、装置、測定系

（セル、電極、媒体）の新発展 化学測定の究極への挑戦一微小質量、 微小サイズ、微小時間、微小濃度等 々電気化学測定法の特徵を発揮した技 術の進歩

1) 電極部分の微小化及び遠隔操作：生 体や環境の in situ, on-site 測定
2) 酸化還元状態、酸塩基状態、イオン 活量（錯形成.溶媒和）等の量的測定

3) 電極の機能化による測定対象の多 様化と高性能化

4) クリーンな試薬源としての電極の 利用

々 他の計測技術との in situ, ex situ での連携 の拡大

动 日常分析法、物性測定法としての応用の 拡大

现環境・資源・エネルギー問題への応用増 加一環境分析・モニター、環境污染除去 処理; $\mathrm{CO}_{2}$ の資源化; クリーン電解合成・ 重合 ; クリーンエネルギー（太陽エネル ギ一変換、燃料電池) ; リチウムイオン 電池、キャパシタ、電気自動車等

动生命科学への応用増加一生体物質分 析; 生命現象 (生体膜・神経・筋肉の機 能・ホルモン作用等) の研究; 生体エネ ルギ一学、遺伝子工学、生体電気触媒等』

ご存知のように、垣内先生はじめこれ までの役員のご尽力で 2008 年から J-STAGE で Review of Polarography にア クセスできるようになっている。

( http://www.jstage.jst.go.jp/browse/revpola rography）書籍の上でしかお目にかかった ことのない先生方の生のお姿が垣間見え る点でも興味深く楽しい。会員の皆さま も是非アクセスしてみて下さい。

人の輪の広がりが暖かなこの日本ポー ラログラフ学会に感謝し、今後とも御支 援とご指導をどうぞよろしくお願い申し 上げます。

（くす・ふみよ、東京薬科大学薬学部、 本会会長) 